\title{
Infracommunities of bat flies (Diptera: Streblidae and Nycteribiidae) of bats (Mammalia: Chiroptera) in three conservation units in the State of Amapá, Brazil
}

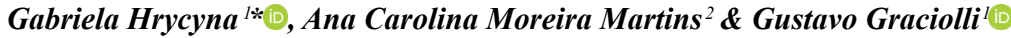 \\ ${ }^{1}$ Universidade Federal do Mato Grosso do Sul, Campo Grande, MS, Brasil \\ ${ }^{2}$ Universidade de Brasília, Brasilia, DF, Brasil \\ *Corresponding author: Gabriela Hrycyna, e-mail: gabriela_hrycyna@hotmail.com
}

HRYCYNA, G, MARTINS A.C.M., GRACIOLLI, G. Infracommunities of bat flies (Diptera: Streblidae and Nycteribiidae) of bats (Mammalia: Chiroptera) in three conservation units in the State of Amapá, Brazil. Biota Neotropica. 19(4): e20180715. http://dx.doi.org/10.1590/1676-0611-BN-2018-0715

\begin{abstract}
Diptera belonging to the families Nycteribiidae and Streblidae are hematophagous ectoparasites, exclusively of bats. The Amapá State is located in the North Region of Brazil. The Amapá represents one of with the lowest rates of deforestation in the country, with approximately $80 \%$ of the territory preserved. Within the State, there are conservation units, Floresta Nacional do Amapá (FNA), Parque Nacional Montanhas do Tumucumaque (PNMT) and Reserva de desenvolvimento Sustentável do Rio Iratapurú (RDSI). These areas represent priority areas for the Conservation of Amazonian Biodiversity. Recently in Amapá studied on the diversity and distribution of bats, however, there are no records of associated arthropod ectoparasites. Therefore, the objective was to describe the pattern of association of Nycteribiidae and Streblidae species on bats in three protected areas of Amapá. Bats were collected through mist nets, where each host had its body visually revised and the Diptera collected were identified through a specific bibliography. One thousand and eighty- six individuals of bats flies were identified, distributed in 52 species ( Streblidae $=49$ and Nycteribiidae $=$ three). Among the three infracommunities, the PNMT infracommunities was the largest found with abundance and richness of bats flies. All species found, represent new occurrences for the Amapá, being these, 18 new records for the North Region and seven new records for Brazil.

Keywords: Hippoboscoidea, Host-parasite relationship, Amazonia, Geographic distribution.

\section{Infracomunidades de moscas ectoparasitas (Diptera: Streblidae e Nycteribiidae) de morcegos (Mammalia: Chiroptera) em três unidades de conservação no Estado do Amapá, Brasil}

\begin{abstract}
Resumo: Dípteros pertencentes as famílias Nycteribiidae e Streblidae são ectoparasitos hematófagos, sendo exclusivamente de morcegos. O estado do Amapá localiza-se na região Norte do Brasil e representa um dos estados com as menores taxas de desmatamento do país, com aproximadamente $80 \%$ do território preservado. Dentro do Estado, existem as unidades de conservação, a Floresta Nacional do Amapá (FNA), o Parque Nacional Montanhas do Tumucumaque (PNMT) e a Reserva de Desenvolvimento Sustentável do Rio Iratapurú (RDS) que representam áreas prioritárias para a Conservação da Biodiversidade da Amazônia. Estudos sobre a diversidade e a distribuição de morcegos têm sido estudada recentemente no Amapá, no entanto, não existem registros de artrópodes ectoparasitos associados. Sendo assim, o objetivo foi descrever padrão de associação das espécies de Nycteribiidae e Streblidae sobre morcegos em três unidades de conservação do Amapá. Os morcegos foram coletados por meio de redes de neblina, onde cada hospedeiro teve seu corpo revisado visualmente e os dípteros coletados foram identificados através de bibliografia específica. Foram identificados 1086 indivíduos de moscas ectoparasitas, distribuídos em 52 espécies (Streblidae $=49$ e Nycteribiidae $=$ três). Entre as três infracomunidades, a infracomunidade de PNMT foi a maior encontrada tanto com relação a abundancia como em riqueza de dípteros ectoparasitas. Todas as espécies encontradas, representam novas ocorrências para o Estado do Amapá, sendo essas, 18 novos registros para a Região Norte e sete novos registros para o Brasil.
\end{abstract}

Palavras-chave: Hippoboscoidea; Interações parasito-hospedeiro; Amazônia; Distribuição geográfica. 


\section{Introduction}

Dipterans of the families Nycteribiidae and Streblidae are hematophagous ectoparasites, exclusively of bats (Wenzel et al. 1966, Marshall 1982). Nycteribiidae presents your distribution mainly in the Old Word. In the American Continent, there are only two genera, Basilia Miranda-Ribeiro, 1903 with 53 species and Hershkovitzia Guimarães \& D'Andretta, 1956 with four species (Graciolli et al. 2007, Graciolli \& Dick 2009, Graciolli 2010). In Brazil were recorded 24 species of Basilia and two of Hershkovitzia (Graciolli 2019a). The Streblidae family occurs mainly in the New Word. There are about 299 species described, with three subfamilies, Nycterophiliinae, Trichobiinae and Streblinae exclusive to the New World (Dick \& Miller 2010, Dick et al. 2016).

Chiroptera represents the second largest mammal order, after Rodentia. They harbor exclusive ectoparasitic arthropod communities (Marshall 1982, Guerrero 1993). In Brazil, there are known 182 species in 69 genera of bats (Nogueira et al. 2018). In the North Region were recorded 144 bats in 63 genera (Reis et al. 2017), with 73 species recorded for Amapá State (Martins et al. 2011).

The Amapá State is located in the North Region of Brazil, on the delta of the Amazon River and making the transition to the highlands of the Guiana Shield. The State represents one of the lowest rates of deforestation in the North Region (INPE 2015). Furthermore, a large proportion of the State's territory $(60 \%)$ is protected in 19 conservation units, divided into federal, state, municipal, full protection and sustainable use units (Drummond et al. 2008).

The diversity and distribution of bats have been studied recently in Amapá (Martins et al. 2006, 2011). However, there are no records of bats flies. Due to that, the objective of this work was to conduct a survey and describe the pattern of association of Nycteribiidae and Streblidae species on bats in three conservation units in the State of Amapá.

\section{Materials and Methods}

The bat flies examined came from a rapid biological inventory of bats performed by Martins et al. (2006, 2011). The inventory followed the Rapid Assessment Program (RAP) developed by Conservation International.

\section{Study area}

Within existing protected areas in the Amapá State, Floresta Nacional do Amapá (FNA), Parque Nacional Montanhas do Tumucumaque (PNMT) and Reserva de Desenvolvimento Sustentável do Rio Iratapurú (RDSI) were chosen to be inventoried. They represent areas considered priorities for the conservation of the biodiversity of the Amazon (Capobianco et al. 2001). To select the collection sites locals, in each conservation area, were used pictures of a satellite to identify the principal vegetation formations. Prioritized regions with more than one environment, or a transition between them (Martins et al. 2006).

The FNA is located right in the center of the State and boasts an area of 4,120,000,000 $\mathrm{m}^{2}$ approximately. The unit is accessed only inland waterway and feature predominantly vegetation of the upland forest, with some stains of flooded forests, "tabocais" (forest of bamboo) and rocky outcrop. The altitude varies from 80 to $450 \mathrm{~m}$ above sea level. This area was inventoried between four and 15th of August 2004, totalizing $21600 \mathrm{~m}^{2} \mathrm{~h}$ (coordinates of collecting points: $01^{\circ} 18^{\prime} 07^{\prime} \mathrm{N}$, 5135'17’'W; 0106'37’N, 5153'37’'W).
The PNMT is located in the northwest region of the State, with an area of $38,700,000,000 \mathrm{~m}^{2}$ approximately. It represents the largest continuous rainforest park in the world and therefore it is accessible only by air or waterways. The vegetation has a predominance of dense forests of mainland, igapó forest (dense ombrophylous alluvial forests), slops forests and dried formations associated with rocky outcrop. The relief varies from 100 to $400 \mathrm{~m}$ above sea level. In this area, two expeditions were carried out. The first occurred between 16 and 25 th of September 2004, and the second expedition occurred between 10 and 20th of January 2005. Totalizing in both expedition $37800 \mathrm{~m}^{2} \mathrm{~h}$ (coordinates of collecting points: $01^{\circ} 35^{\prime} 45^{\prime \prime} \mathrm{N}, 52^{\circ} 29^{\prime} 32^{\prime \prime} \mathrm{W}$; $02^{\circ} 11^{\prime} 36^{\prime \prime} \mathrm{N}, 54^{\circ} 35^{\prime} 15^{\prime \prime} \mathrm{W}$; $03^{\circ} 12^{\prime} 59^{\prime \prime} \mathrm{N}, 52^{\circ} 011^{\prime} 10^{\prime \prime} \mathrm{W} ; 01^{\circ} 23^{\prime} 13^{\prime} \mathrm{N}, 51^{\circ} 55^{\prime} 39^{\prime \prime} \mathrm{W}$; $01^{\circ} 50^{\prime} 41^{\prime \prime} \mathrm{N}$, $\left.52^{\circ} 44^{\prime} 28^{\prime \prime} \mathrm{W}\right)$.

The RDSI is located in the southwest of the State, with about of $8,060,000,000 \mathrm{~m}^{2}$. In addition, only accessible by waterways and features a predominance of an upland forest with a high concentration of Castanheiras-do-Brazil (Bertholletia excelsa Humb. \& Bonpl., 1808) and therefore there are traditional populations who commercially exploit the resource. The relief varies from 100 to $500 \mathrm{~m}$ above sea level. This area was inventoried between 12 and 20th of November, totaling $16200 \mathrm{~m}^{2} \mathrm{~h}$ (coordinates of collecting points: $00^{\circ} 16^{\prime} 35^{\prime \prime} \mathrm{N}, 5^{\circ} 06^{\prime} 24^{\prime \prime} \mathrm{W}$;

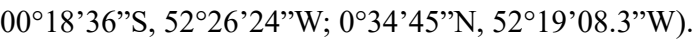

\section{Capture of host and bat flies}

The details of the capture of bat were described in Martins et al. $(2006,2011)$. Each night, 10 mist-net $(12 \times 2.5)$ were opened from 18:00 to $24: 00 \mathrm{~h}$. In each host had the body visually reviewed and the bat flies were removed with the help of tweezers and stored in Eppendorf type tubes containing ethanol $70 \%$, and a label with the data collection. The identification of bat flies was made using the keys presented by Guimarães \& D'Andretta (1956), Guimarães $(1966,1977)$ and Guerrero (1993, 1994a, b, 1995a, b, 1996). The bat flies identified were deposited in the Coleção Zoológica de Referência, Universidade Federal do Mato Grosso do Sul, Campo Grande.

\section{Data analysis}

The description of the infracommunities (community of parasite infrapopulations in a single host) (Bush et al. 1997) found in common in each conservation. It was analyzed only the hosts species with at least two infested bats. In each infracommunities, it was calculated the absolute number of occurrence and relative frequency (quotient between the absolute frequency of parasites and the total number of the population in each host). Information about all infracommunities are described in the supplementary material (Table S1).

\section{Results}

At the total, it was found 207 infested bats for the three conservation units. Among the bats species, only 10 were in common for the tree localities. In FNA from 52 bats of 18 species were infested by 29 species of bat flies. In RDSI, we found 47 bats for 17 species infested by 28 species of bat flies. Finally, PNMT, 108 individuals of 25 species were infested by 41 species of bat flies.

In relation to the bat flies, were identified 1086 individuals, distributed in 50 species and two subspecies (Steblidae $=49$ and Nycteribiidae $=3$ ). Nycteribiidae family was represented by three 
species of Basilia. For Streblidae, Trichobius dugesioides dugesioides Wenzel, $1966(\mathrm{n}=134)$ was the most abundant bat fly, follow of Trichobius dugesioides phyllostomus Guerrero, $1998(\mathrm{n}=110)$, Trichobius costalimai Guimarães, $1938(\mathrm{n}=98)$ and Mastoptera minuta (Costa Lima, 1921) (n=90) (Tables 1, 2 and 3).

Four species of bats, Pteronotus parnelli (Gray, 1843), Artibeus planirostris (Spix, 1823), Phyllostomus elongatus (Geooffroy, 1810) and Sturnira tildae De la Torre, 1959, were found in all Conservation Units We recorded a total of 39 composition of infracommunities bat flies
$(\mathrm{FLONA}=11, \mathrm{PNMT}=16, \mathrm{RDSI}=12)$. . . parnelli presented the highest quantity of different parasites composition, with 11 infracommunities in all conservation's units. Despite this, the composition of the bat flies species infracommunities were different in each conservation unit. Strebla consocia Wenzel, 1976, Trichobius dugesioides phyllostomus, Trichobius longipes (Rudow, 1871) were in common for the three units. Trichobius costalimai and Trichobius jobligi Wenzel, 1966 were exclusive for PNMT and Mastoptera minuta and Strebla galindoi Wenzel, 1966 for RDSI (Table 4).

Table 1. Bats species, with a number of infested individuals. Their respective bat flies species and abundance in Floresta Nacional do Amapá Conservation Unit. $\mathrm{Ni}=$ number of individuals infested. $\mathrm{N}=$ number of individuals.

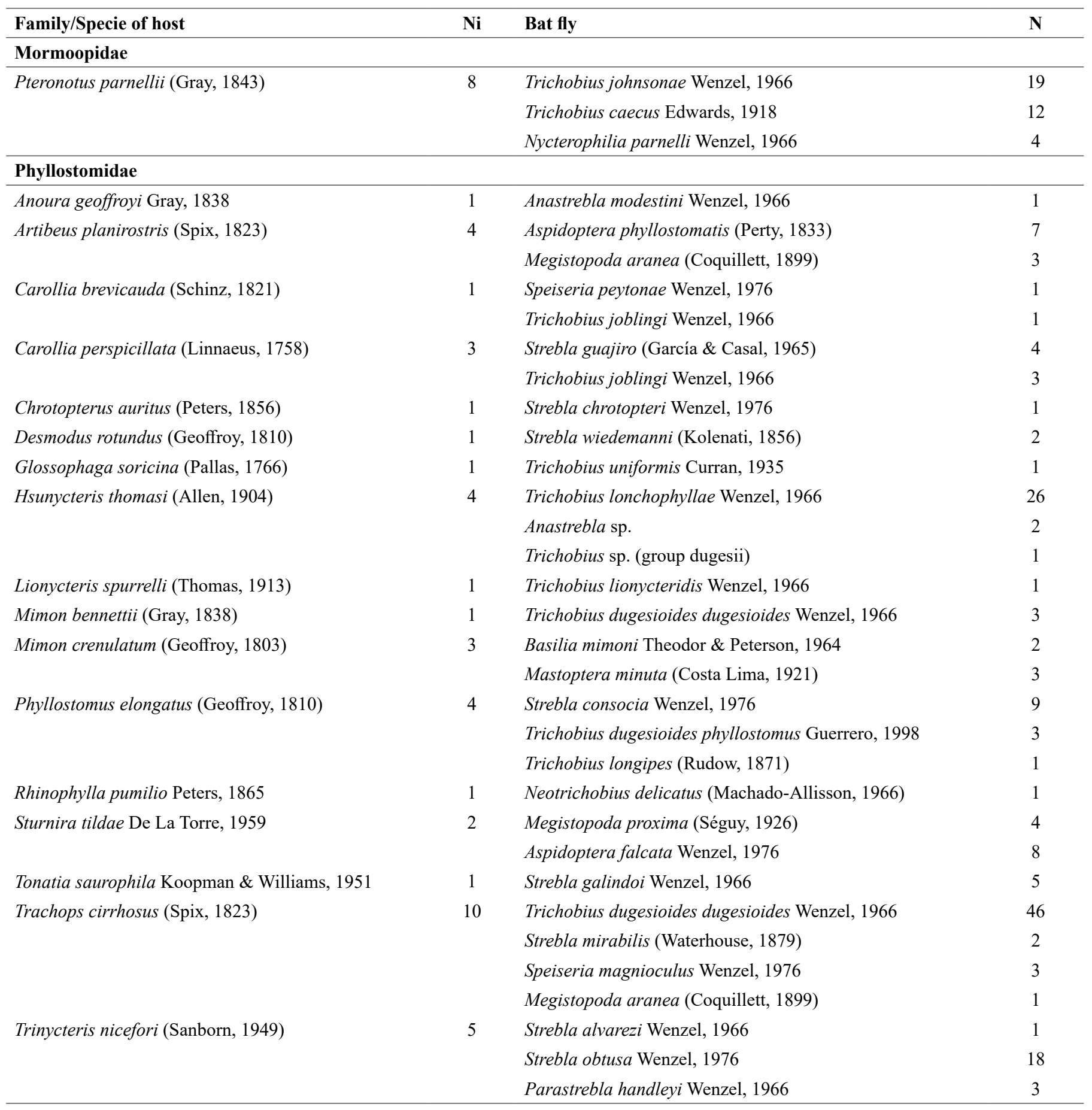


Hrycyna, G. et al.

Table 2. Bats species, with a number of infested individuals. Their respective bat flies species and abundance in Parque Nacional Montanhas do Tumucumaque Conservation Unit. $\mathrm{Ni}=$ number of individuals infested. $\mathrm{N}=$ number of individuals.

\begin{tabular}{|c|c|c|c|}
\hline Family/Specie of host & $\mathbf{N i}$ & Bat fly & $\mathbf{N}$ \\
\hline \multicolumn{4}{|l|}{ Emballonuridae } \\
\hline Rhynchonycteris naso (Wied-Neuwied, 1820) & 1 & Strebla asternalis Wenzel, 1976 & 1 \\
\hline \multicolumn{4}{|l|}{ Mormoopidae } \\
\hline Pteronotus parnellii (Gray, 1843) & 7 & Trichobius johnsonae Wenzel, 1966 & 18 \\
\hline \multicolumn{4}{|l|}{ Noctilionidae } \\
\hline \multirow[t]{2}{*}{ Noctilio leporinus (Linnaeus, 1758) } & 1 & Noctiliostrebla aitkeni Wenzel, 1966 & 18 \\
\hline & & Paradyschiria lineata Kessel, 1925 & 8 \\
\hline \multicolumn{4}{|l|}{ Phyllostomidae } \\
\hline Artibeus obscurus (Schinz, 1821) & 1 & Neotrichobius bisetosus Wenzel, 1976 & 1 \\
\hline \multirow[t]{3}{*}{ Artibeus planirostris (Spix, 1823) } & 14 & Aspidoptera phyllostomatis (Perty, 1833) & 15 \\
\hline & & Megistopoda aranea (Coquillett, 1899) & 22 \\
\hline & & Metelasmus pseudopterus Coquillett, 1907 & 2 \\
\hline \multirow[t]{2}{*}{ Carollia perspicillata (Linnaeus, 1758) } & 1 & Strebla guajiro (García \& Casal, 1965) & 1 \\
\hline & & Trichobius joblingi Wenzel, 1966 & 2 \\
\hline \multirow[t]{3}{*}{ Chrotopterus auritus (Peters, 1856) } & 5 & Strebla chrotopteri Wenzel, 1976 & 14 \\
\hline & & Trichobius johnsonae Wenzel, 1966 & 1 \\
\hline & & Trichobius dugesioides dugesioides Wenzel, 1966 & 12 \\
\hline Lophostoma brasiliense Peters, 1866 & & Trichobius silvicolae Wenzel, 1976 & 1 \\
\hline \multirow[t]{3}{*}{ Lophostoma silvicola d'Orbigny, 1836} & 7 & Mastoptera minuta (Costa Lima, 1921) & 23 \\
\hline & & Trichobius silvicolae Wenzel, 1976 & 13 \\
\hline & & Pseudostrebla riberoi Costa Lima, 1921 & 1 \\
\hline Mimon crenulatum (Geoffroy, 1803) & 4 & Basilia mimoni Theodor \& Peterson, 1964 & 13 \\
\hline Phylloderma sternops (Peters, 1865) & 1 & Strebla christinae Wenzel, 1966 & 2 \\
\hline \multirow[t]{4}{*}{ Phyllostomus discolor (Wagner, 1843) } & 14 & Strebla hertigi Wenzel, 1966 & 31 \\
\hline & & Trichobius costalimai Guimarães, 1938 & 63 \\
\hline & & Trichobioides perspicillatus (Pessôa \& Galvão, 1936) & 7 \\
\hline & & Trichobius dugesioides dugesioides Wenzel, 1966 & 2 \\
\hline \multirow[t]{6}{*}{ Phyllostomus elongatus (Geoffroy, 1810) } & 17 & Strebla consocia Wenzel, 1976 & 34 \\
\hline & & Trichobius dugesioides phyllostomus Guerrero, 1998 & 76 \\
\hline & & Trichobius longipes (Rudow, 1871) & 9 \\
\hline & & Trichobius costalimai Guimarães, 1938 & 4 \\
\hline & & Trichobius joblingi Wenzel, 1966 & 2 \\
\hline & & Trichobius sp. parasiticus complex & 10 \\
\hline
\end{tabular}


Continuation Table 2.

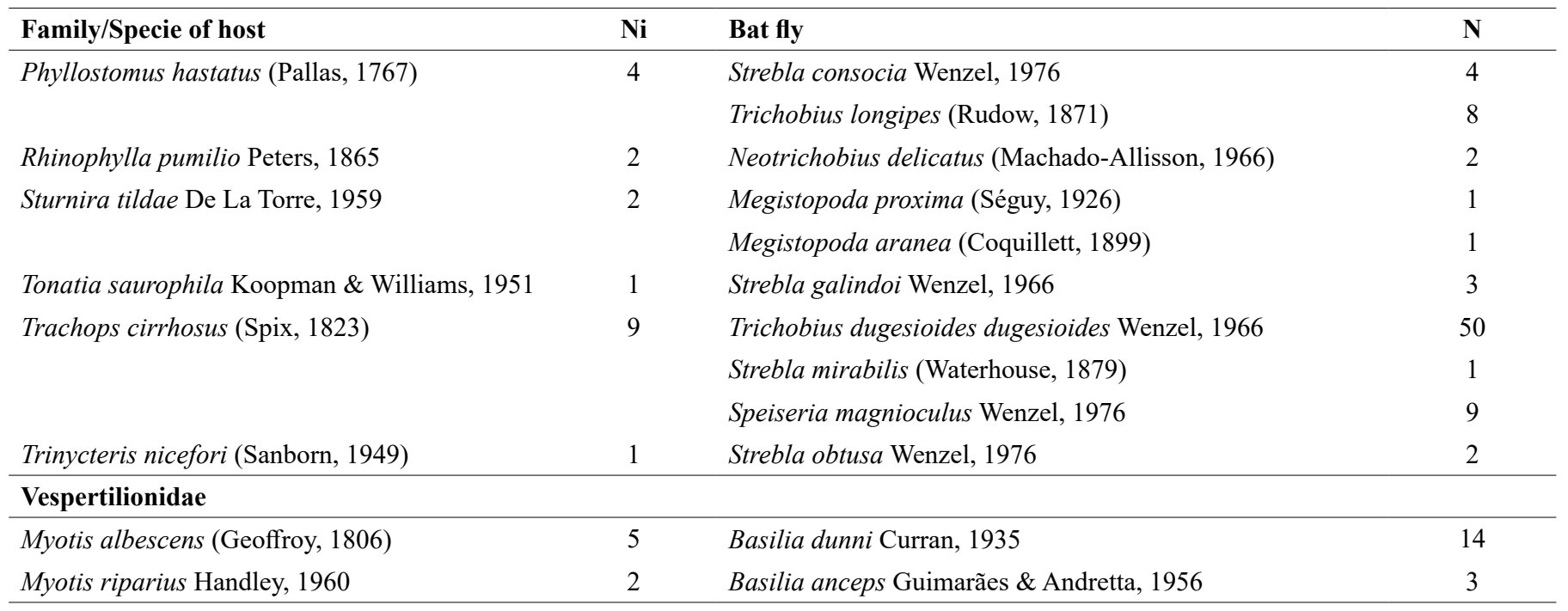

All species recorded in this work represent the first occurrence to the State of Amapá. Among these, 17 species and two genera of Streblidae are recorded for the first time in the North Region. This increased to 58 and 15 the number of species and genera respectively for the region. In relation to the Nycteribiidae, Basilia anceps Guimarães \& D'Andretta, 1956 is registered for the first time for the North Region, increased to eight the number of species for the region. Strebla asternalis Wenzel, 1976, Strebla matsoni Wenzel, 1976, Paradyschiria lineata Kessel, 1925, Speiseria peytonae, Wenzel 1976, Speiseria magnioculus Wenzel, 1976, Trichobius lionycteridis Wenzel, 1966 and Trichobius macrophylli Wenzel 1966 are recorded for the first time in the Brazil, increasing to 92 the number of Streblidae species for the country (Table 5).

\section{Discussion}

The richness of species found in this work confirms the information that the Brazilian Amazon presents a very large diversity of species of bat flies (Graciolli \& Bernard 2002, Graciolli \& Linardi 2002, Graciolli 2019a, 2019b). With the new occurrences of this work, the North Region remains with 58 species of Streblidae, with the same number in species to the Central-West Region. The Southeast Region has 53 species recorded, follow with Northeast with 48 and finally the South Region with 33 species (Barbier \& Bernard 2017, Graciolli 2019b, Barbier et al. 2019). Despite this, the regions Central-West and Southeast have a greater amount in a number of genera of Streblidae, each with 18 genera (Graciolli 2019b). In the Northeast are found 14 genera, in the South 13 and finally, the North with the current work remains with 15 genera of Streblidae (Barbier \& Bernard 2017, Graciolli 2019b, Barbier et al. 2019).

With the family Nycteribiidae this relationship is reversed. The Southeast represents the Region richer, with 18 species, following with the South Region with 13 species, Central-West with 11, the Northeast with four species and with the current work, the North Region remains with eight species of Nycteribiidae (Barbier \& Bernard 2017, Graciolli 2019a, Barbier et al. 2019). Although the North and Northeast Regions not be as expressive in quantity of species, it represents the only regions that in addition the genus Basilia, also occurs the genus Hershkovitzia
(H. cabala Peterson \& Lacey, 1985, H. inaequalis Theodor, 1967 and Hershkovitzia sp.) (Peterson \& Lacey 1985, Graciolli 2001, Graciolli \& Bernard 2002, Santos et al. 2013, Barbier \& Bernard 2017, Graciolli 2019a)

Previously, Pará was the State with the highest number of species of Streblidae for the North Region of Brazil, with 28 species. Then stay Rondônia and Roraima with 14 species each and Amazonas with nine species (Graciolli 2019b). The high amount of species of bat flies found to Amapá $(\mathrm{N}=52)$, demonstrates that much of the diversity species of bat flies for the region remains unknown (Graciolli \& Linardi 2002, Graciolli \& Bernard 2002, Graciolli 2019b).

The new registers for Brazil were already known for another country of the South and Central America. The species S. asternalis and $S$. matsoni where known only for Venezuela (Wenzel 1976, Guerrero 1994b, Frank et al. 2014). S. magnioculus still be known for Venezuela, has also been found in Peru (Wenzel 1976, Guerrero 1994b, Frank et al. 2014). On the contrary, some species have a large distribution in South and Central America, but there was no occurrence for Brazil. Such as, S. peytonae which that is known for Bolivia, Colombia, Peru, Venezuela, Belize and Honduras (Wenzel 1976, Guerrero 1994b, Dick 2013, Frank et al. 2014, Dick et al. 2016) (Table 5).

In the present work, Trichobioides perspicillatus (Pessôa \& Galvão, 1936) represents the first occurrence of genus and species for the North Region of Brazil. Previously the species still had occurrence for the Regions Northeast (Bahia, Maranhão, Pernambuco and Sergipe), Central-West (Distrito Federal and Mato Grosso do Sul) and Southeast (Minas Gerais) (Graciolli 2019b). Despite not have previously registered for the North Region, previous work has already pointed out that the species is found in the Amazonian ecoregion (Barbier \& Bernard 2017). Anastrebla modestini Wenzel, 1966 also represents the first occurrence of genus/species for the North Region. Previously this species was described only for the regions South (Paraná, Santa Catarina and Rio Grande do Sul), Southeast (São Paulo, Rio de Janeiro and Minas Gerais) and Central-West (Distrito Federal and Goiás) (Graciolli 2019b). Its restricted distribution was probably the distribution of the host (Anoura geoffroyi Gray, 1838), which for North Region is known only for States of Amapá and Pará (Zortéa \& Velazco 2017) (Table 5). 
Hrycyna, G. et al.

Table 3. Bats species, with a number of infested individuals. Their respective bat flies species and abundance in Reserva de Desenvolvimento Sustentável Rio Iratapuru Conservation Unit. $\mathrm{Ni}=$ number of individuals infested. $\mathrm{N}=$ number of individuals.

\begin{tabular}{|c|c|c|c|}
\hline Family/Specie of host & $\mathbf{N i}$ & Bat fly & $\mathbf{N}$ \\
\hline \multicolumn{4}{|l|}{ Mormoopidae } \\
\hline \multirow[t]{3}{*}{ Pteronotus parnellii (Gray, 1843) } & 9 & Trichobius johnsonae Wenzel, 1966 & 7 \\
\hline & & Nycterophilia parnelli Wenzel, 1966 & 2 \\
\hline & & Mastoptera minuta (Costa Lima, 1921) & 1 \\
\hline \multicolumn{4}{|l|}{ Phyllostomidae } \\
\hline \multirow[t]{2}{*}{ Artibeus lituratus (Olfers, 1818) } & 2 & Megistopoda aranea (Coquillett, 1899) & 1 \\
\hline & & Paratrichobius longicrus (Miranda-Ribeiro, 1907) & 2 \\
\hline Artibeus planirostris (Spix, 1823) & 5 & Aspidoptera phyllostomatis (Perty, 1833) & 7 \\
\hline \multirow[t]{2}{*}{ Chrotopterus auritus (Peters, 1856) } & 2 & Strebla chrotopteri Wenzel, 1976 & 3 \\
\hline & & Trichobius dugesioides dugesioides Wenzel, 1966 & 2 \\
\hline Lampronycteris brachyotis (Dobson, 1879) & 1 & Strebla obtusa Wenzel, 1976 & 5 \\
\hline Lionycteris spurrelli (Thomas, 1913) & 1 & Trichobius lionycteridis Wenzel, 1966 & 2 \\
\hline \multirow[t]{3}{*}{ Lophostoma silvicola d'Orbigny, 1836} & 3 & Mastoptera minuta (Costa Lima, 1921) & 1 \\
\hline & & Trichobius silvicolae Wenzel, 1976 & 3 \\
\hline & & Strebla galindoi Wenzel, 1966 & 1 \\
\hline \multirow[t]{2}{*}{ Macrophyllum macrophyllum (Schinz, 1821) } & 2 & Strebla matsoni Wenzel, 1976 & 1 \\
\hline & & Trichobius macrophylli Wenzel, 1966 & 8 \\
\hline \multirow{4}{*}{ Phyllostomus elongatus (Geoffroy, 1810) } & & Trichobius dugesioides phyllostomus Guerrero, 1998 & 31 \\
\hline & & Trichobius longipes (Rudow, 1871) & 22 \\
\hline & & Strebla galindoi Wenzel, 1966 & 5 \\
\hline & & Mastoptera minuta (Costa Lima, 1921) & 34 \\
\hline \multirow[t]{3}{*}{ Phyllostomus hastatus (Pallas, 1767) } & 1 & Strebla consocia Wenzel, 1976 & 1 \\
\hline & & Trichobius longipes (Rudow, 1871) & 9 \\
\hline & & Mastoptera minuta (Costa Lima, 1921) & 21 \\
\hline Rhinophylla pumilio Peters, 1865 & 2 & Neotrichobius delicatus (Machado-Allisson, 1966) & 3 \\
\hline \multirow[t]{2}{*}{ Sturnira tildae De La Torre, 1959} & 2 & Megistopoda proxima (Séguy, 1926) & 4 \\
\hline & & Aspidoptera falcata Wenzel, 1976 & 1 \\
\hline \multirow[t]{2}{*}{ Tonatia saurophila Koopman \& Williams, 1951} & 2 & Strebla galindoi Wenzel, 1966 & 5 \\
\hline & & Trichobius silvicolae Wenzel, 1976 & 1 \\
\hline Trachops cirrhosus (Spix, 1823) & 1 & Trichobius dugesioides dugesioides Wenzel, 1966 & 19 \\
\hline \multicolumn{4}{|l|}{ Vespertilionidae } \\
\hline Myotis albescens (Geoffroy, 1806) & 1 & Basilia dunni Curran, 1935 & 2 \\
\hline
\end{tabular}


Infracommunities of bat flies in Brazil

Table 4. Bat species with their respective infracommunity. $\mathrm{N}=$ Absolute number of occurrence. $A R \%=$ Values of relative abundance.

\begin{tabular}{|c|c|c|c|c|c|c|c|c|}
\hline Infracommunity FNA & $\mathbf{N}$ & AR\% & Infracommunity PNMT & $\mathbf{N}$ & AR\% & Infracommunity RDS & $\mathbf{N}$ & AR\% \\
\hline Pteronotus parnellii (N 8) & & & Pteronotus parnellii (N 7) & & & Pteronotus parnellii (N 9) & & \\
\hline T. johnsonae & 3 & $37 \%$ & T. johnsonae & 5 & $71 \%$ & T. caecus & 6 & $66 \%$ \\
\hline \multirow[t]{2}{*}{ T. caecus } & 2 & $25 \%$ & T. caecus & 1 & $14 \%$ & T. caecus + M. minuta & 1 & $11 \%$ \\
\hline & & & & & & $\begin{array}{l}\text { N. delicatus }+N . \text { parnelli }+ \\
\text { T. johnsonae }\end{array}$ & 1 & $11 \%$ \\
\hline
\end{tabular}

Artibeus planirostris (N 4)

A. phyllostomatis

M. aranea

A. phyllostomatis +

M. aranea

Phyllostomus elongatus

(N 4)

S. consocia + T. dugesioides

phyllostomus

S. consocia

T. longipes
Artibeus planirostris (N 14)

$250 \% \quad$ A.phyllostomatis

$1 \quad 25 \% \quad M$. aranea

$25 \%$

A. phyllostomatis + M. aranea

+ M. pseudopterus

A. phyllostomatis + M. aranea

Phyllostomus elongatus (N 17)

$2 \quad 50 \% \quad$ S. consocia + T. dugesioides

phyllostomus

$1 \quad 25 \% \quad$ T. dugesioides phyllostomus

$125 \%$

T. dugesioides phyllostomus +

S. consocia $+T$. longipes

T. costalimai

T. dugesioides phyllostomus +

T. longipes

S. consocia $+T$. longipes +

Trichobius sp. parasiticus complex

T. dugesioides phyllostomus + S. consocia $+T$. joblingi
Artibeus planirostris (N 5)

\begin{tabular}{ll}
7 & $50 \%$ \\
4 & $28 \%$ \\
& \\
2 & $14 \%$ \\
\hline 1 & $7 \%$
\end{tabular}

Phyllostomus elongatus

(N 6)

$7 \quad 41 \% \quad$ T. dugesioides phyllostomus

+ S. consocia $+T$. longipes

+ M. minuta

$3 \quad 17 \% \quad$ S. consocia + T. dugesioides $\quad 1 \quad 16 \%$ phyllostomus

$3 \quad 17 \% \quad$ T. dugesioides phyllostomus $\quad 1 \quad 16 \%$

$+S$. galindoi $+T$. longipes

$5 \% \quad$ T. dugesioides phyllostomus $1 \quad 16 \%$
Sturnira tildae (N 2)

M. proxima

M. proxima + A. falcata
Sturnira tildae (N 2)

$1 \quad 50 \% \quad$ M. proxima
Sturnira tildae (N 2)

$150 \% \quad$ M. proxima

$150 \%$

$1 \quad 50 \% \quad$ A. falcata
Some species have significantly increased its distribution in Brazil. Previously T. lonchophyllae Wenzel, 1966 and Strebla harderi Wenzel, 1976 were known only for the regions Central-West (Distrito Federal) and Southeast (Minas Gerais and Rio de Janeiro - T. lonchophyllae). T. johnsonae Wenzel, 1966, B. anceps and Nycterophilia parnelli Wenzel, 1966 were recorded only in the regions Central-West (Distrito Federal, Goiás - B. anceps, Mato Grosso - N. parnelli and Mato Grosso do Sul-T.johnsonae). Strebla hoogstraali Wenzel, 1966 was known only for the State of Maranhão. The other new records for the North Region (Strebla chrotopteri Wenzel, 1976, Trichobius tiptoni Wenzel, 1976 and Trichobius dugesii Townsend, 1891) already had a wider distribution along the other regions of Brazil (Graciolli 2019b). Although, the specie S. curvata Wenzel, 1976 already has an occurrence for the North Region, the identification is in dubious (Santos et al. 2012) (G. Graciolli personal communication) (Table 5).

In PNMT was found in greater richness and abundance of bat flies (41 species, $\mathrm{N}=559$ ), bat ( 25 species, $\mathrm{N}=108$ ) and consequently of infracommunities $(\mathrm{N}=16$ ) (Tables 2 and 4$)$. This is probably the area have received two expeditions, while the others had only an expedition (Martins et al. 2006, 2011). The frequency of species richness in the infracommunities is similar than the frequency found by others works (Santos et al. 2013, Barbier \& Graciolli 2016, Dornelles \& Graciolli 2017). 
Hrycyna, G. et al.

Table 5. Registered of new occurrences for the Region North and for Brazil. $\left({ }^{1}\right.$ Wenzel 1966, ${ }^{2}$ Wenzel 1976, ${ }^{3}$ Guerrero $1994 \mathrm{~b},{ }^{4}$ Dick $2013,{ }^{5}$ Frank et al. 2014, ${ }^{6}$ Dick et al. 2016, ${ }^{7}$ Graciolli 2019b).

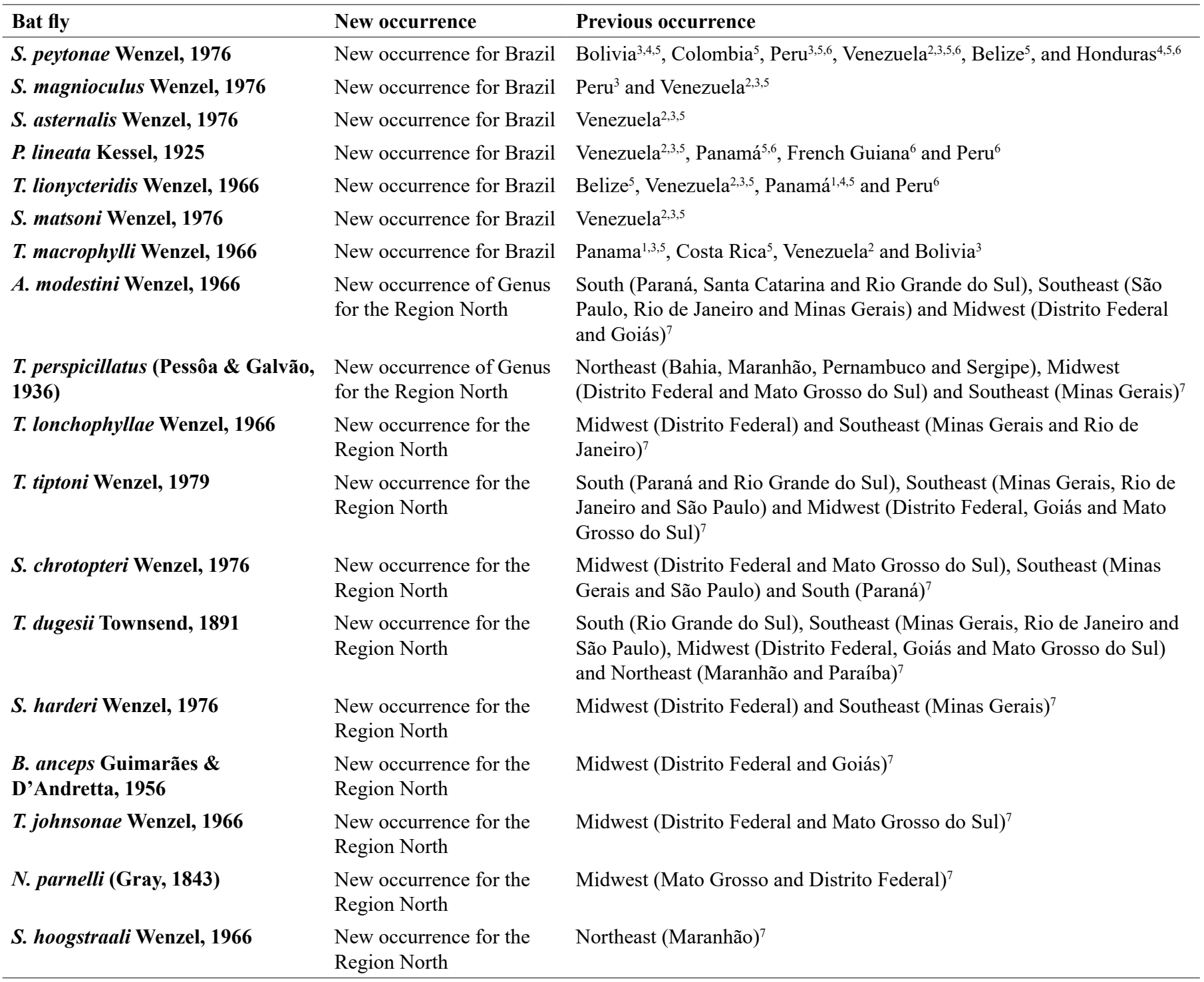

\section{Conclusion}

This work represents the first record of bat flies (Streblidae and Nycteribiidae) for Amapá State. The number of species of bat flies up to 50 species and two subspecies for the State of Amapá, being these 18 new records for the North Region of the country and seven new records for Brazil. In addition, the infracommunities found in the three conservations units of Amapá are described.

\section{Supplementary material}

The following online material is available for this article:

Table S1 - All the infracommunities found in the three Conservation Units.

\section{Acknowledgment}

We thank the Coordenação de Aperfeiçoamento de Pessoal de Nível Superior (CAPES - process 1757817), the Conselho Nacional de Desenvolvimento Científico e Tecnológico (CNPq - 304616/2015-0) and the International Conservation by support.

\section{Author Contributions}

Ana Carolina Moreira Martins: Contribution to data collection. Gabriela Hrycyna: Contribution to manuscript preparation.

Gustavo Graciolli: Contribution to critical revision, adding intellectual content; Contribution to manuscript preparation.

\section{Conflicts of interest}

The authors declares that they have no conflict of interest related to the publication of this manuscript. 


\section{References}

BARBIER, E. \& BERNARD, E. 2017. From the Atlantic Forest to the borders of Amazonia: species richness, distribution, and host association of ectoparasitic flies (Diptera: Nycteribiidae and Streblidae) in northeastern Brazil. Parasitol Res. 116: 3043.

BARBIER, E. \& GRACIOLLI, G. 2016. Community of bat flies (Streblidae and Nycteribiidae) on bats in the Cerrado of Central-West Brazil: host, aggregation, prevalence, infestation intensity, and infracommunities. Stud Neotrop Fauna E. 51: 176-187.

BUSH, A.O., LAFFERTY, K.D., LOTZ, J.M., SHOSTAK, A.W. 1997. Parasitology meets ecology on its own terms: Magolis et al. revisited. J. Parasitol. 83(4): 575-583.

CAPOBIANCO, J.P.R., VERÍSSIMO, A., MOREIRA, A., SAWYER, D., SANTOS, I., PINTO, L.P. 2001. Biodiversidade na Amazônia Brasileira Avaliação e identificação de ações prioritárias para a conservação, utilização sustentável e repartição de benefícios. Instituto Socioambiental, Estação da liberdade, São Paulo.

DICK, C.W. 2013.Review of bat flies of Honduras, Central America (Diptera: Streblidae). J. Parasitol. Res. 437696: 1-17.

DICK, C.W., GRACIOLLI, G., GUERRERO, R. 2016. Family Streblidae. Zootaxa. 1: 784-802.

DICK, C.W. \& MILLER, J. 2010. Streblidae (bat flies). In Manual of Central American Diptera (B.V. BROWN, A. BORKENT, J.M. CUMMING, D.M. WOOD, N.E. WOODLEY, M.A. ZUMBADO, eds). NRC Research Press, Ottawa, v.2, p.1249-1260.

DORNELLES, G.D.P. \& GRACIOLLI, G. 2017. Streblidae bat flies on phyllostomid bats from an Island off the coast o São Paulo, Brazil. Pap. Avulsos de Zool. 57: 31-36.

DRUMMOND, J.A., DIAS, T.C.A.C., BRITO, D.M.C. 2008. Atlas das Unidades de Conservação do Estado do Amapá MMA/IBAMA-AP; GEA/SEMA, Macapá, p.127.

FRANK, R., MÜNTER, J., SCHULZE, J., LISTIN, A., KLIMPEL, S. 2014. Macroparasites of Microchiroptera: Bat Ectoparasites of Central and South America. In Bats (Chiroptera) as Vectors of Diseases and Parasites (S. KLIMPEL \& H. MEHLHORN, eds). Springer - Verlag Berlim Heidelberg, p.87-130.

GRACIOLLI, G. 2001. Distribuição geográfica e hospedeiros quirópteros (Mammalia, Chiroptera) de moscas nicteribidas américas (Diptera, Nycteribiidae). Rev. Bras. Zool. 18: 307-322.

GRACIOLLI, G. 2010. Nycteribiidae (Bat flies, Spider bat flies). In Manual of Central American Diptera (B.V. BROWN, A. BORKENT, J.M. CUMMING, D.M. WOOD, N.E. WOODLEY, M.A. ZUMBADO, eds). NRC Research Press, Ottawa, v.2, p.1261-1266.

GRACIOLLI, G. 2019a. http://fauna.jbrj.gov.br/fauna/faunadobrasil/1145 (último acesso em 17/04/2019)

GRACIOLLI, G. 2019b. http://fauna.jbrj.gov.br/fauna/faunadobrasil/2624 (último acesso em 17/04/2019)

GRACIOLLI, G. \& BERNARD, E. 2002. Novos registros de moscas ectoparasitas (Diptera, Streblidae e Nycteribiidae) em morcegos (Mammalia, Chiroptera) do Amazonas e Pará, Brasil. Rev. Bras. Zool. 19(1): 77-86.

GRACIOLLI, G. \& Dick C.W. 2009.A new species of Basilia Miranda-Ribeiro (Diptera: Nycteribiidae) from Honduras, parasite of Bauerus dubiaquercur (Van Gelder) (Chiroptera: Vespertilionidae: Antrozoinae). Zootaxa. 1972: 59-64.

GRACIOLLI, G. \& LINARDI, P.M. 2002. Some Streblidae and Nycteribiidae (Diptera: Hippoboscoidea) from Maracá Island, Roraima, Brazil. Mem. Inst. Oswaldo Cruz. 97: 139-141.

GUERRERO, R. 1993. Catalogo de los Streblidae (Diptera: Pupipara) parasitos de murcielagos (Mammalia: Chiroptera) del Nuevo Mundo. I. Clave para los gêneros y Nycterophiliinae. Acta biol. venez. 14: 61-75.

GUERRERO, R. 1994a. Catalogo de los Streblidae (Diptera: Pupipara) parasitos de murcielagos (Mammalia: Chiroptera) del Nuevo Mundo. II. Los grupos: Pallidus, Caecus, Major, Uniformis y Longipes del gênero Trichobius Gervais, 1844. Acta biol. venez. 15: 1-18.
GUERRERO, R.1994b. Catalogo de los Streblidae (Diptera: Pupipara) parasitos de murcielagos (Mammalia: Chiroptera) del Nuevo Mundo. IV. Trichobiinae con alas desarrolladas. Bol. Entomol. Venez. 9: 161-192.

GUERRERO, R. 1995a. Catalogo de los Streblidae (Diptera: Pupipara) parasitos de murcielagos (Mammalia: Chiroptera) del Nuevo Mundo. III. Los grupos: Dugesii, Dunni y Phyllostomae del gênero Trichobius Gervais, 1844. Acta biol. venez. 15: 1-27.

GUERRERO, R. 1995b. Catalogo de los Streblidae (Diptera: Pupipara) parasitos de murcielagos (Mammalia: Chiroptera) del Nuevo Mundo. V. Trichobiinae con alas reducidas o ausentes y miscelaneos. Bol. Entomol. Venez. 10: 135-160.

GUERRERO, R. 1996. Catalogo de los Streblidae (Diptera: Pupipara) parasitos de murcielagos (Mammalia: Chiroptera) del Nuevo Mundo. VI. Streblinae. Acta biol. Venez. 16: 1-25.

GUIMARÃES, L.R. 1966. Nycteribiid batflies from Panama (Diptera: Nycteribiidae). In Ectoparasites of Panama. Field Museum of Natural History (R.L. WENZEL \& V.J. TIPTON eds). Chicago, IL., p.393-404.

GUIMARÃES, L.R. 1977. Supplemantary note on Venezuelan bat flies (Diptera: Nycteribiidae). The Great Basin nat. 37: 221-224.

GUIMARÃES, L.R. \& D’ANDRETTA, M.A.V. 1956. Sinopse dos Nycteriidae (Diptera) do Novo Mundo. Arq. Zool. 10: 1-184.

INPE. 2015. http://www.obt.inpe.br/OBT/assuntos/programas/amazonia/prodes (último acesso em 17/04/2019)

MARSHELL, A.G. 1982. Ecology of Insects Ectoparasitic on Bats. In Ecology of Bats (T.H. KUNZ ed.). Ecology of Bats. Plenum Press, New York, p.369-401.

MARTINS, A.C.M., BERNARD, E. GREGORIN, R. 2006. Inventários biológicos rápido de morcegos (Mammalia, Chiroptera) em três unidades de conservação do Amapá, Brasil. Rev. Bras. Zool. 23: 1175-1184.

MARTINS, A.C.M., BERNARD, E. GEGORIN, R. WANUYZE, A.S.S. 2011. Filling data gaps on the diversity and distribution of Amazonian bats (Chiroptera): The case of Amapá, easternmost Brazil. Zoologia. 28: 177-185.

NOGUEIRA, M.R., LIMA, I.P., GARBINO, G.S.T., MORATELLI, R., TAVARES, V.C., GREGORIN, R., PERACCHI, A.L., 2018. Updated checklist of Brazilian bats: version 2018.1. Comitê da Lista de Morcegos do Brasil - CLMB. Sociedade Brasileira para Estudos de Quirópteros (Sbeq). http://www.sbeq.net/updatelist (último acesso em 10/06/2019).

PETERSON, B.V. \& LACEY, B.V. 1985. A new species of Hershkovitzia (Diptera: Nycteribiidae) from Brazil, with a key to the described species of the genus. Proc. Entomol. Soc.Wash. 87: 578-582.

REIS, N.R., PERACCHI, A.L., BATISTA, C.B. LIMA, I.P. PEREIRA, A.D. 2017. História natural do Morcegos Brasileiros. Technical Books Editora, Rio de Janeiro, p.416.

SANTOS, F.G.A., CAlouro, A.M., SOUZA, S.F., LAGUE, B.M., MARCIENTE, R., FAUSTINO, C.L., SANTOS, G.J.L., CUNHA, A.O. 2012. Ectoparasitismo em uma assembleia de morcegos em um fragmento florestal no estado do Acre, Brasil. Acta Vet. Bras. 6 (3): 211-218.

SANTOS, C.L.C., PEREIRA, A.C.N., BASTOS, V.J.C., GRACIOLLI, G. REBÊLO, M.M. 2013. Parasitism of ectoparasitic flies on bats in the northern Brazilian cerrado. Acta Parasitol. 58: 207-214.

WENZEL, R.L. 1976. The Streblid bat flies of Venezuela (Diptera: Streblidae). Brigham Young Univ Sci B Biol S. 20(4): 1-177.

WENZEL, R.L., TIPTON, V.J., KIEWLIZ, A. 1966. The streblid battlies of Panama (Diptera: Calyptera: Streblidae). In Ectoparasites of Panama (R.L. WENZEL, V.J. TIPTON eds). Field Museum Natural History, Chicago, p.405-408.

ZORTÉA, M. \& VELAZCO, P.M. 2017. Subfamília Glossophaginae Bonaparte, 1845. In História natural do Morcegos Brasileiros (N. R. REIS, A.L. PERACCHI, C.B. BATISTA, I.P. LIMA, A.D. PEREIRA eds). História natural do Morcegos Brasileiros. Technical Bokks Editora, Rio de Janeiro, p.150-172. 